\title{
INFLUENCE OF ONLINE BRAND COMMUNITY ENGAGEMENT ON BRAND TRUST AND BRAND LOYALTY
}

\author{
Joshua Kofi Doe \\ Central University, Ghana, PO Box DS 2310, Dansoman, Accra
}

\begin{abstract}
This study examines the effect of online brand community customer engagements on brand loyalty,through various online customer-to-community relationships, and trust. Data was randomly collected from 720 members of an online brand community page using an online questionnaire and analysed with Structural Equations Modelling (SEM). The study found that online brand community activities influenced customer-product relationships, and not customer-brand nor customer-company relationships. None of the customer relationships mediate the link between online brand community and trust. Trust, however partially mediates between customer-product relationships and brand loyalty, as well as between customer-company relationships and brand loyalty. Trust of the online community was confirmed to lead to loyalty. For industry practitioners, these findings support the need to ensure favourable customer/product related activities, experience and word of mouth within the online community. It also demonstrates the possibility of brand extension and brand trust at lower costs. The paper contributes to industrial and academic knowledge of virtual brand community and its effects.
\end{abstract}

\section{KEYWORDS}

Virtual Brand Community, Customer Relationships, Brand Loyalty, Brand Trust

\section{INTRODUCTION}

Social media such as Facebook, Twitter, MySpace and LinkedIn, have become popular online attraction sites for consumer interactions (Alharthey, 2020). These social media create online communities that allow more dynamic roles in consumer to firm interaction and virtual presence. Individuals, professional groups, governments, and businesses alike are currently experimenting with social media marketing strategies, in what appears to be an exceptionally viral way to get messages (Saji, Chauhan, \& Pillai, 2013; Sohail, Hasan, \& Sohail, 2020). In this regard, researchers on social media have found that brand loyalty is enhanced through brand 
IADIS International Journal on WWW/Internet

experiences and emotional connections, particularly through the use of social media brand community activities (Iglesias, Singh, \& Batista-Foguet, 2011). These virtual brand community activities such as entertainment, interaction, and customization (Sohail et al., 2020) invariably build upon trust (Alharthey, 2020) that can yield loyalty. The horizon of marketing therefore has been broadened.

Within the context of a sub-Saharan developing country such as Ghana, a few companies seem to have engaged customers on facebook sites over the last couple of years. As part of their marketing drive to maintain brand communities, these firms developed social media campaigns as a strategic tool to engage customers.

Given this increasing use and popularity of these social media as brand communities in Ghana, studies that seek to examine brand loyalty (Barnet \& Ferris, 2016), trust on social media (Alharthey, 2020), social media marketing (Sohail, Hasan, \& Sohail, 2020) are worth doing. However, there is a paucity of research on how social media brand communities affect the brand within the context of sub-Saharan Africa. There is also limited research on the contribution of the social media brand community in the achievement of brands in Ghana. Specifically whether online brand community leads directly to brand loyalty, brand trust, as well as brand relationship, or have other moderators and mediators, are unclear . In this regard, this study is positioned to fill the research gap of examining a) whether brand community (Facebook) affects its relationship with customers, and b) the extent to which the online community affects brand loyalty.

\section{LITERATURE REVIEW}

\subsection{Social Media}

Kaplan and Haenlein (2010) define social media as a group of internet based applications propelled by Web 2.0, allowing the creation and exchange of user generated content. Web 2.0 is a term that describes a new way of using the internet where content is endlessly altered by all operators in a sharing and collaborative way (Kaplan and Haenlein 2010). In this way, users now create and consume content, thereby adding value to the site (Campbell et al., 2011). This has progressed from simple information recovery to interactivity, interoperability, and collaboration (Campbell et al., 2011), enabling brands to listen to consumers and respond (Fournier \& Avery, 2011). This has resulted in a fundamental marketing strategy shift in how organizations and customers relate to each other (Angel \& Sexsmith, 2009). Social media marketing therefore is the connection between brands and consumers, that offer personal channels and currency for user-centred networking and social interaction (Chi, 2011).

The phrases, social networking and social media are often used interchangeably. However, social media is an interactive online application that allows users to unite by generating personal information profiles and inviting friends and colleagues to have access to those profiles (Kaplan and Haenlein 2010). Social networking on the other hand, is the practice of expanding the number of one's business, or social contact by making connections through individuals, often through social media sites such as Facebook, Twitter, LinkedIn, and Google+. Thus, social media is the environment in which social networking takes place. These online interactive environment in which social networking takes place and has altered the way in which consumers gather information and make buying decisions. 
Popular social media sites that are accessible in Ghana include social networks (Facebook, Myspace, and LinkedIn), micro-blogs (Twitter, Plurk, and Friend Feed), reviews and ratings (Yelp, Amazon, and Trip Advisor), video (YouTube and Vimeo), messengers (WhatsApp, imo, Snapchat, Telegram, Wechat, Viber etc.), photo sharing (Instagram, Snapchat, Pinterest etc.), and more. Facebook had over 800 million active users with over $50 \%$ of them logging on everyday as at 2011, while Twitter had 200 million registered users with 50 million active users logging in every day as at 2011 (Taylor, 2011). On these spaces where virtual brand communities exist, customer engagement includes reading content, watching brand related videos, commenting on a content, sharing a content with others, rating products and companies, creating awareness for offline activities around the brand or product, and creating and posting user generated content (Bayraktar \& Yildirim, 2019). Thus through the use of social media sites, managers can find out what is being said about a brand and they can also connect with consumers (Reyneke, Pitt, \& Berthon, 2011).

\subsection{Virtual Brand Community}

Virtual Brand Communities (VBCs) can be described as aggregations of consumers that occur on a virtual space due to their interest in a brand or product (Georgi \& Mink, 2012), a group of people who share the same interest in a particular brand or product (Casaló, Favián and Guinalíu 2008) or the site[s] of complex brand meaning creation and consumption efforts (Muñiz $\&$ Schau, 2007). The essence of VBC therefore is to generate loyalty to the brand through the creation of brand experiences, based on common interest.

In the discussion of what makes a virtual brand community (VBC) cohesive and loyal to a brand, Casaló, Favián, and Guinalíu (2008) found that trust for a VBC leads to increased participation, and positive VBC participation experience leads to more loyalty of the brand. Thus trust is an important factor to guarantee the survival of VBC's . Trust itself is influenced by security (Cha, 2009), individual users' participation, group unity and awareness (Casaló, Favián, \& Guinalíu, 2008). The effect of trust and its antecedents (Casaló, et al., 2008) demonstrates the power of VBC interaction between consumers can have on buying behaviour. In anticipating why people join vrtual communities, Bayraktar and Yildirim (2019) also categorised anteceents of customer engagement participation as social interaction ties, trust, social identification, reciprocity, perceived usefulness, perceived enjoyment, renumeration, perceived brand image, brand satisfaction, social image enhancement, and altruism.

The online interaction between customers for instance, offers the chance to mingle with other customers as a fundamental part of the consumer experience and social networking (Georgia $\&$ Mink, 2012). This enables consumers to play a more dominant role in influencing each other with their consumption decisions (Georgi \& Mink, 2012). In this regard, Georgi \& Mink (2012) discovered seven factors that influence the participation experiences of VBC to include content, security, hedonic (the emotional aspects of consumers' interactions with products), quality, atmosphere, convenience, and social factors. Habibi, Laroche, and Richard (2014) however focused on the types of virtual brand relationships, and emphasised four types of customer relationships open to virtual brand community participants: customer-product, customer-brand, customer-company and customer-other customer relationships. In the same vein, Mangold $\&$ Faulds (2009) argued that consumers feel more engaged with products and companies when they have the option to submit feedback. Thus, it is imperative for retailers to be cognisant of 
IADIS International Journal on WWW/Internet

the quality of their social media presence even when consumers are the creators of these virtual communities. This is because it increasingly influences how consumers shop

In a brand community group dynamics such as the case of virtual communities, group norms represent the set of shared goals, beliefs, and values that group members follow. The nature and culture of social media group norms affect the way its members interpret and attach meaning to brands and products (Muñiz \& Schau, 2007). Thus community members within a strong social group are more likely to have group intentions to accept the organization's offer in online communities or not (Zeng, Huang, \& Dou, 2009). Moreover, VBC members value offers that are relevant to the theme of their community.

\subsection{Brand}

"A 'brand' is a name, term, sign, symbol or design, or a combination of them intended to identify the goods and services of one seller or group of sellers and to differentiate them from those of competitors" (Keller, 1998). Brands may be represented by a personality and a signature tune to capture the hearts of consumers and keep them loyal (Batra, Ahuvia, \& Bagozzi, 2012). Strong brands therefore enable the consumer to identify products, evaluate their quality, and make it easier for the customers to develop attitudes and expectations. Brands also make shopping more efficient as it tends to reduce perceived risks of purchase (Keller, 1998). Well-known brands are capable of developing favourable attitudes and perceptions more easily, leading to loyalty (Kapferer, 2008).Brand loyalty in essence, yields brand equity (Aaker, 1991). Brand equity may give the brand an efficient base for line or brand extensions as the image and personality of the brand is easily carried over to the new products, giving it a head start (Aaker, 1996). This supports the view that in a competitive business environment, brands are not just symbols that serve as identifiers but have an economic function (Kapferer, 1997). Such economic function is its ability to form an exclusive, positive and prominent meaning in the minds of consumers (Kapferer, 1997).

\subsection{Brand Trust}

Gaining the trust of a brand audience is essential to building brand loyalty (Lau \& Lee, 1999). While Lau and Lee (1999) viewed brand trust as the willingness to rely on the brand, Moorman et al. (1992) described trust as the willingness to rely on an exchange partner confidently. Chaudhuri \& Holbrook (2001) also define brand trust as consumer's willingness to rely on the ability of the brand to perform its stated function. Thus brand trust is the willingness and keenness to depend on another party in the face of risk. In relationship-marketing literature, trust has been viewed as a determinant of the loyalty (Berry, 1983), and has been recognised in recent studies as a key variable in long-term relationships with customers, which in turn positively affects brand loyalty (Ming et al., 2011; Bowen and Bowen, 2020). This apparently confirms earlier views that brand trust leads to higher levels of loyalty as trust creates exchange relationships that are highly valued (Morgan and Hunt, 1994). Chaudhuri and Holbrook (2001) summarises this phenomenon that brand trust strongly influences the customer's attitude and repurchase loyalty. 


\subsection{Brand Loyalty}

Brand loyalty has been widely discussed within the offline brand loyalty literature, giving prominence to two dimensions of the concept. These are behavioural and attitudinal loyalty (Balginger and Rubinson, 1996). To widen this conceptual view, Olver (1997) had offered a conceptual framework of brand loyalty, showing the full spectrum of brand loyalty based on a hierarchy of effects model with cognitive, affective, conative ( behavioural intent) and action (repeat purchase behavior) dimensions.

Oliver (1997) defines loyalty as capturing its multi dimensionality as "a deeply held commitment to rebuy or patronise a preferred product/service consistently in the future, thereby causing repetitive same-brand or same brand-set purchase, despite the situational influences and marketing efforts having the potential to cause switching behaviour". Chaudhuri (1997) also defines brand loyalty as the preference of customer to buy a single brand, or a particular brand name in a product class regularly. Thus the customer repurchases the brand and resists switching to another. Aaker's (1991) description of brands as the measure of attachment that a customer has towards a brand conceptualises brand loyalty as a pyramid with five tiers: the switchers; satisfied, but habitual buyers; satisfied buyers with switching cost; brand likers; and committed buyers. Brand loyalty includes intention to repurchase, and brand commitment (Bennett \& Rundle-Thiele, 2002). Jacoby et al. (1977) had found that a high brand loyalty indicates a tendency to buy only a single brand in a product category, not a multi-loyalty purchase intention. Brand loyalty therefore occurs when consumers perceive that the brand offers the right product features, images or level of quality at the right price. This perception may translate into repeat purchase resulting in loyalty. Brand Loyalty may occur due to a long history of using a product and trust that has developed as a consequence of the long usage. Aaker (1991) states that the core of a brand equity is based on customer loyalty. Therefore if customers buy with respect to features, price and convenience with little concern to the brand name, there is perhaps little equity (Aaker, 1991).

\subsection{Hypothesis Development}

Consumer engagement on social media can be measured by consumers' propensity to invest the resources of themselves in activities in the social media group activity such as value co-creation, social interaction, knowledge sharing/storing, and word of mouth (WOM) (Liu, Lee, Liu and Chen, 2018). While this has been found to moderate between the various customer-virtual brand relationships (product, brand, company) and trust (Habibi et al., 2014), Stokburger-Sauer (2010), however, suggests a significant relationship between online brand community engagement and consumer personal relationships with product, brand, and company. This study examines whether the social media brand community engagement leads to enhanced consumer-product relationship, consumer-brand relationship, and consumer-company relationship. It is therefore hypothesised that:

\section{H1:Online brand community engagement influences customer/product relationship.}

H2:Online brand community engagement influences customer/brand relationship

\section{H3:Online brand community engagement influences customer/company relationship}


IADIS International Journal on WWW/Internet

Habibi et al. (2014) developed and tested a model on how consumers' relationships with the elements of a brand community based on social media (brand, product, company, and other consumers) influences brand trust. Apart from customer relationship with other customers, Habibi et al. (2014) reported a significant relationship between the other three constructs and brand trust among the online brand community participants. This study tests these hypotheses under the current contexts, and therefore hypothesise the following:

\section{H4: Customer/product relationship influences trust among customers.}

H5: Customer/company relationship influences trust among customers.

H6: Customer/brand relationship influences trust among customers.

Brand trust resulting from online community engagement has been reported to lead to brand loyalty (Laroche, Habibi, \& Richard, 2013). This study therefore hypothesise that:

H7: Brand trust leads to brand brand loyalty

\section{METHODOLOGY}

Items for the measurement of customer-product relation, customer-brand relation, and customer-company relation were all adapted from Habibi, Laroche, and Richard (2014) and Casalo, Flavian, and Guinali (2010). Question items for trust were adapted from Habibi et al. (2014), brand loyalty were adapted from Casalo, Flavian, and Guinali (2010) and the social media engagement construct was adapted from Liu, Lee, Liu, and Chen (2018). Data was conveniently collected with questionnaires conducted in a central shopping mall in Ghana. A sample size of 740 useable responses were received from users of various brand communities. The data was analysed with Structural Equations Modelling (SEM) in SmartPLS software (Ringle, Wende, \& Smith, 2005).

\section{DATA ANALYSIS}

Data analysis and its results are presented in below.

\subsection{Respondents Background}

Table 1 below demonstrates the general demographic background of respondents. The data shows that majority of the respondents are male, between the ages of 18 and 47, with above high school education, and are earning up to approximately $\$ 1,000$ per month. By Ghanaian standards, these are people who have enough to invest into online brand activity engagements. 
Table 1. Respondent Characteristics

\begin{tabular}{|c|c|c|c|c|c|}
\hline & Freq. & Percent & & Freq. & Percent \\
\hline Gender & & & Income & & \\
\hline Male & 650 & $87.84 \%$ & Below GhC 1000 & 188 & $25.41 \%$ \\
\hline \multirow[t]{3}{*}{ Female } & 90 & $12.16 \%$ & GhC 1000 - GhC 2999 & 198 & $26.76 \%$ \\
\hline & 740 & $100.00 \%$ & GhC 3000 - GhC 4999 & 66 & $8.92 \%$ \\
\hline & & & GhC 5000 - GhC 6999 & 63 & $8.51 \%$ \\
\hline Age & & & Above GhC 7000 & 65 & $8.78 \%$ \\
\hline $18-27 y r s$ & 319 & $43.11 \%$ & No Response & 160 & $21.62 \%$ \\
\hline $28-37 \mathrm{yrs}$ & 150 & $20.27 \%$ & & 740 & $100.00 \%$ \\
\hline $38-47 \mathrm{yrs}$ & 136 & $18.38 \%$ & Occupation & & \\
\hline $48-57 \mathrm{yrs}$ & 63 & $8.51 \%$ & Private sector employee & 160 & $21.62 \%$ \\
\hline $58-67 \mathrm{yrs}$ & 41 & $5.54 \%$ & Self employed & 199 & $26.89 \%$ \\
\hline \multirow[t]{3}{*}{$67+$ yrs } & 31 & $4.19 \%$ & Civil servant & 147 & $19.86 \%$ \\
\hline & 740 & $100.00 \%$ & Public servant & 148 & $20.00 \%$ \\
\hline & & & Unemployed & 81 & $10.95 \%$ \\
\hline Education & & & Retired & 5 & 0.006757 \\
\hline Primary & 45 & $6.08 \%$ & & 740 & $100.00 \%$ \\
\hline JHS/SHS & 88 & $11.89 \%$ & & & \\
\hline Diploma & 245 & $33.11 \%$ & & & \\
\hline Bachelor & 256 & $34.59 \%$ & & & \\
\hline \multirow[t]{2}{*}{ Post graduate } & 106 & $14.32 \%$ & & & \\
\hline & 740 & $100.00 \%$ & & & \\
\hline
\end{tabular}

\subsection{Measurement Model Validation}

Table 2 below shows the descriptive statistics of the variables used in the study. Table 2 Descriptive Statistics.

Table 2

\begin{tabular}{lllll}
\hline & Min & Max & Mean & Std. Dev. \\
\hline Online Brand Community & 1 & 5 & 2.81 & 1.19 \\
Customer/Product Relation & 1 & 5 & 3.04 & 1.24 \\
Customer/Brand Relation & 2 & 5 & 3.28 & 1.19 \\
Customer/Company Relation & 1 & 5 & 2.98 & 1.15 \\
Brand Trust & 1 & 5 & 2.76 & 1.17 \\
Brand Loyalty & 1 & 5 & 2.86 & 1.29 \\
\hline
\end{tabular}

In order to run structural equation modelling analysis in SmartPLS, the data must first meet conditions of data validity and reliability as outlined by Chin (1998). Reliability refers to the extent to which the data collection instrument produces consistent results if replicated in another study (Saunders et al., 2006). Composite Reliability (CR) and Cronbach's Alpha ( $\alpha$ ) tests were used to assess reliability of the research the instrument consistency. Chin (1998) recommended that an instrument indicated acceptable reliability if the Composite Reliability (CR) and Cronbach's Alpha $(\alpha)$ were greater than 0.70 .

Convergent validity tested the extent to which two or more indicators measure the same variable/construct. For example, customer/product relation was measured with four (4) indicators; hence it was important to test whether all these four indicators measure the concept 
IADIS International Journal on WWW/Internet

of customer/product relation well or not. Chin (1998) recommended that a construct exhibited acceptable validity of the items if the Average Variance Extracted (AVE) value was above 0.50.

Table 3 below shows the results for the test for reliability and validity of the constructs/variables used in the study. The CR values were between 0.75 and 1.00 , well above the recommended threshold of 0.70 . This implied that the items used to measure the variables/constructs showed high reliability and would produce consistent results if replicated on another sample. The AVE values were between 0.58 and 1.00, again showing acceptable convergent validity of measures since they were well above the recommended 0.50 value.

Table 3. Construct Reliability and Validity

\begin{tabular}{lll}
\hline & Composite & Average Variance \\
& Reliability (CR) & Extracted (AVE) \\
\hline Brand Loyalty & 0.75 & 0.61 \\
Customer/Brand Relation & 0.95 & 0.90 \\
Customer/Company Relation & 1.00 & 1.00 \\
Customer/Product Relation & 0.85 & 0.66 \\
Online Brand Community & 0.89 & 0.73 \\
Trust & 0.80 & 0.58 \\
\hline
\end{tabular}

Discriminant validity tested whether the items selected to measure a variable actually do so. This was tested in two ways: first, with the Fornell-Larcker criterion, the diagonal values were greater than the off-diagonal values (the pair-wise correlation between factors) as shown in Table 4 and cross loadings were higher on their respective construct (i.e. above 0.60) than on other constructs as shown in Table 5: both depicted acceptable discriminant validity.

Table 4. Discriminant Validity of Variables/Constructs

\begin{tabular}{llllll}
\hline Brand Loyalty & $\begin{array}{l}\text { Customer/ } \\
\text { Brand } \\
\text { Relation }\end{array}$ & $\begin{array}{l}\text { Customer/ } \\
\text { Company } \\
\text { Relation }\end{array}$ & $\begin{array}{l}\text { Customer/ } \\
\text { Product } \\
\text { Relation }\end{array}$ & $\begin{array}{l}\text { Online } \\
\text { Brand } \\
\text { Community }\end{array}$ & Trust \\
\hline Brand Loyalty & 0.782 & & & & \\
Customer/Brand Relation & -0.054 & 0.948 & & & \\
Customer/Company Relation & 0.339 & 0.088 & 1 & & \\
Customer/Product Relation & 0.547 & 0.073 & 0.295 & 0.813 & 0.857 \\
Online Brand Community & 0.009 & 0.201 & -0.016 & 0.227 & -0.06 \\
Trust & 0.562 & -0.125 & 0.335 & 0.496 & \\
\hline
\end{tabular}

Three (3) items with a loading of below 0.60 on their respective constructs were removed to attain acceptable discriminant validity. These were one item each from Brand Loyalty (BLOYAL2), Customer/Brand Relation (BRND3) and Customer/Company Relation (COMP1). 
Table 5. Cross Loadings of Items/Indicators on Variables

\begin{tabular}{lllllll}
\hline & $\begin{array}{l}\text { Brand } \\
\text { Loyalty }\end{array}$ & $\begin{array}{l}\text { Customer/ } \\
\text { Brand } \\
\text { Relation }\end{array}$ & $\begin{array}{l}\text { Customer/ } \\
\text { Company } \\
\text { Relation }\end{array}$ & $\begin{array}{l}\text { Customer/ } \\
\text { Product } \\
\text { Relation }\end{array}$ & $\begin{array}{l}\text { Online Brand } \\
\text { Community }\end{array}$ & $\begin{array}{l}\text { Trust } \\
\text { BCOM1 }\end{array}$ \\
BCOM2 & 0.111 & -0.007 & 0.016 & 0.217 & 0.845 & 0.052 \\
BCOM3 & -0.079 & 0.328 & -0.045 & 0.178 & 0.877 & 0.046 \\
BLOYAL1 & 0.906 & -0.059 & 0.362 & 0.559 & 0.019 & -0.144 \\
BLOYAL3 & 0.634 & -0.016 & 0.115 & 0.231 & -0.015 & 0.543 \\
BRND1 & -0.044 & 0.932 & 0.07 & 0.048 & 0.160 & -0.097 \\
BRND2 & -0.057 & 0.963 & 0.093 & 0.085 & 0.213 & -0.134 \\
BTRUST1 & 0.386 & -0.131 & 0.22 & 0.429 & 0.017 & 0.753 \\
BTRUST2 & 0.371 & -0.105 & 0.268 & 0.26 & -0.169 & 0.670 \\
BTRUST3 & 0.514 & -0.057 & 0.281 & 0.425 & -0.011 & 0.849 \\
COMP2 & 0.339 & 0.088 & 1.000 & 0.295 & -0.016 & 0.335 \\
PROD1 & 0.415 & 0.087 & 0.391 & 0.840 & 0.213 & 0.433 \\
PROD2 & 0.480 & -0.001 & 0.200 & 0.814 & 0.174 & 0.350 \\
PROD4 & 0.446 & 0.082 & 0.113 & 0.786 & 0.162 & 0.418 \\
\hline
\end{tabular}

PLS Structural Model Results

First, the bootstrap method in SmartPLS 3 (Ringle, Wende, \& Becker, 2015) was run to determine the significance of the hypothesized relations in the research model. It was evident that three (3) path relationships were statistically non-significant, namely: Customer/Brand Relation -> Trust; Online Brand Community -> Customer/Brand Relation and Online Brand Community $\rightarrow$ Customer/Company Relation. Overall, four (4) path relationships showed statistical significance: Customer/Company Relation -> Trust and Online Brand Community -> Customer/Product Relation was at 95\% significance level whilst Customer/Product Relation -> Trust and Trust -> Brand Loyalty was at 99\% significance level. The results and further details are shown in Table 6 below.

Table 6. Path Significance

\begin{tabular}{|c|c|c|c|c|}
\hline & $\begin{array}{l}\text { Original } \\
\text { Sample }(\mathrm{O})\end{array}$ & $\begin{array}{l}\text { T Statistics } \\
(|\mathrm{O} / \mathrm{STDEV}|)\end{array}$ & $\begin{array}{l}\mathrm{P} \\
\text { Values }\end{array}$ & Remark \\
\hline Customer/Brand Relation -> Trust & -0.176 & 0.883 & 0.378 & n.s \\
\hline $\begin{array}{l}\text { Customer/Company Relation -> } \\
\text { Trust }\end{array}$ & 0.219 & 2.198 & 0.028 & $\mathrm{p} \leq 0.05$ \\
\hline $\begin{array}{l}\text { Customer/Product Relation -> } \\
\text { Trust }\end{array}$ & 0.444 & 4.022 & 0.000 & $\mathrm{p} \leq 0.01$ \\
\hline $\begin{array}{l}\text { Online Brand Community -> } \\
\text { Customer/Brand Relation }\end{array}$ & 0.201 & 0.922 & 0.357 & n.s \\
\hline $\begin{array}{l}\text { Online Brand Community -> } \\
\text { Customer/Company Relation }\end{array}$ & -0.016 & 0.129 & 0.897 & n.s \\
\hline $\begin{array}{l}\text { Online Brand Community -> } \\
\text { Customer/Product Relation }\end{array}$ & 0.227 & 2.291 & 0.022 & $\mathrm{p} \leq 0.05$ \\
\hline Trust -> Brand Loyalty & 0.562 & 9.601 & 0.000 & $\mathrm{p} \leq 0.01$ \\
\hline
\end{tabular}

\section{Test for Mediation}

The study assessed the following: (i) whether the type of relationships established mediates the relationship between online brand community and trust; and (ii) whether trust mediates the 
IADIS International Journal on WWW/Internet

relations between the types of customer relationships and brand loyalty. To assess mediation, guidelines by Hair et al. (2013) were followed. First, the model was made with only the exogenous and the endogenous constructs. Then the model was run with the introduction of the mediating constructs. If the relationship is not statistically significant, then there is no mediation, however, if there exists a significant relationship, then there is mediation. This mediation is full if the mediator makes the original relationship between the independent and dependent variables non-significant. Otherwise, only partial mediation is established.

\section{FINDINGS}

Online Brand Community and Customer Relations- Overall, the results revealed that online brand community led positively and significantly to customer/product relation $(\beta=0.227$, $\mathrm{p} \leq 0.05$.). This showed that online brand community improved customers' consumption of the product. In this case, customer purchase of product increased due to the organisations online community activities. Online brand community did not lead to customer/brand relation $(\beta=0.201$, n.s). Online brand community was once more found to exhibit a non-significant negative relationship with customer/company relation $(\beta=-0.016$, n.s.). In effect, therefore, online community improved customers' relations mainly with the product, but not the company nor brand. This implies that online brand community can cause the increased consumption of a product as a group activity and not necessarily as a preference for the brand, nor the company. Overall, online brand community explained only a small percentage of the variance for the three types of relations tested, customer/product relation $(\mathrm{R} 2=0.051 \%)$, customer/brand relation $\left(\mathrm{R}^{2}=0.040\right)$, and customer/company relation $(\mathrm{R} 2=0.00)$. This implies that the online brand community is not necessarily the main reason why customers relate well with the product, brand or company.

Customer Relations and Trust- The study tested the impact of customers' relationships with the product, brand and company through online communities on their level of trust. Results showed that customer-product relation $(\beta=0.444, \mathrm{p} \leq 0.01)$, as well as customer-company relation $(\beta=0.219, \mathrm{p} \leq 0.05)$ significantly helped build trust among customers. However, customer/brand relations $(\beta=0.176$, n.s.), which negatively related to the level of trust among customers, was not statistically significant. This means that customer-product relationship could mediate between online brand community and brand trust. This mediation effect implies that an online brand community can lead to brand trust only through the experience with the product. Even though customer-company relationship leads to brand trust directly, it however does not mediate between online community and brand trust. Customer-brand relationship neither led to brand trust, nor mediated between online community and brand trust. Overall, the three types of customers' relation with the product, brand and company on online brand communities (in this case the online brand community of firms studied) explained about $30 \%$ of the variance for customers' trust $\left(\mathrm{R}^{2}=0.303\right)$.

Trust and Brand Loyalty- The results showed that the trust-loyalty relationship is strong $(\beta=0.562, p \leq 0.01)$ and trust accounts for about $30 \%$ of why customers are loyal to the brand. This means that it is important for brands to work towards winning the trust of customers of the online community, as this greatly led to brand loyalty, which is found to spur repurchase and generate increased performance. 
Result of Mediating Relationships- Results reveal that the types of relations do not mediate the link between online brand community and trust. For example, the direct relationship between online brand communication and trust $(\beta=-0.232$, n.s.) was not statistically significant. Hence, there could not be a mediating effect by customer/product, customer/brand and customer/company relations. On the other hand, trust seems to have some mediating effect on some of the relationships and brand loyalty. For instance, the strength of the direct relationship between customer/product relations and brand loyalty $(\beta=0.562, \mathrm{p} \leq 0.01)$ reduced, but maintained statistical significance with the introduction of the mediating construct, trust $(\beta=0.494, p \leq 0.0)$. This shows that trust only partially mediates the relationship. Similarly, trust only partially mediates the relationship between customer/company relations and brand loyalty as the strength of the direct relationship reduced but was still statistically significant with the inclusion of trust (i.e. from $\beta=0.355, p \leq 0.0$ to $\beta=0.335, p \leq 0.0$ ). Nonetheless, trust does not mediate the relationship between customer/brand relations and brand loyalty $(\beta=-0.058$, n.s) due to the non-significant nature of the direct relationship.

\section{DISCUSSION}

The data revealed that online brand community activities caused the increased consumption of the product as a group activity and not necessarily as a preference for the brand, nor the company. This customer-product relationbship is experienced and judged by the customer evaluation of the difference between expectations of performance (or some other norm of performance) and the actual performance of the product as perceived after its consumption (Bayraktar \& Yildirim, 2019). This is also been seen as a key basis for the stability of customer-brand relationships (Bayraktar \& Yildirim, 2019). The customer-product relationship was the only significant consumer relationship resulting from virtual brand community engagement. The result confirms some findings from earlier studies (Muñiz \& Schau, 2007; Mangold \& Faulds, 2009; Barnet \& Ferris, 2016) as well as come current studies (Alharthey, 2020) that online brand community interaction between consumers results in opinion leadership and group consumption decisions.

Even thouth customer-product relationship did not mediate between virtual brand community and trust, it led to brand trust. This implies that online brand community can only lead to brand trust through experience with the product, and not the brand image nor company relationship. This result partly confirms Habibi, Laroche, and Richard's (2014) report that customer-product and customer-company relationships influenced trust, while customer-brand relationship did not influence brand trust. These trend of results is an indication that the online community activitists joined online community probably due to their already existing need o know and consume more of the product community they joined. This points to the marketing orientation that consumers buy what they need, and therefore marketers must first determine what their customers needs and satisfy these needs at a profit.

Even though the customer-company relationship leads to brand trust directly, it is not significantly affected by online brand community engagement and therefore does not mediate between online community and brand trust. This partly supports Habibi, Laroche, and Richard's (2014) contention that customer-company relationship influences brand trust. Thus participating in the virtual brand community activities does not mean that the brand or company is liked. In other words, people can be on a virtual brand community for other reasons than having a 
IADIS International Journal on WWW/Internet

relationsip or likeness for the company that initiated or manages the community activities.Customer-brand relationship neither led to brand trust, nor mediated between online community and brand trust. This result supports Habibi, Laroche, and Richard (2014), but differs from that of Casaló, Flavián and Miguel (2008) who reported that virtual community has a positive influence on consumer commitment to customer-brand relationship. Thus while customer-brand product relationship is enhanced through the virtual brand community acvities, customer-brand relationship itself is no enhanced. This result is another indication that brand audience are more particular about the brand product experience than other experiences they may perceive. The online customer - to -customer relationships for instance may matter for continuous engagement, but the customer-to-product experience is the most significant factor that can yield trust and loyalty.

Trust of the online community was confirmed to lead to loyalty. The finding supports the report of Casaló, Favián, and Guinalíu (2008) as well as Bowen and Bowen (2020) that brand trust influences loyalty to the brand.These results imply that online brand community can lead to brand trust only through the experience with the product, and not the brand image nor company relationship. Therfore brand loyaly through virtual brand community engagements can easily be achieved if the customer -product experiences are good, and thus lead to trust.

\section{MANAGERIAL IMPLICATIONS}

Managerial implications of the findings above include the following:

Organizations using online community as a marketing communications tool need to ensure favourable customer/product related activities, experience and word of mouth within the community. This can influence more purchase of the brand through opinion leadership.

Awareness creation of brand extensions can be done at very reduced marketing cost, as the brand community increased its purchases as a community activity even if they dislike the company or other elements of the brand.

Offline programs pertaining to brands need to be promoted as part of the online brand community activities to enhance the personal interaction with customers. This personal interaction can improve the customer/company relationship, thereby enhancing trust.

It is important for organisations to work towards winning the trust of customers of the online community, as this greatly leads to brand loyalty, which is found to spur repurchase behaviour and generate increased performance.

\section{LIMITATIONS AND RECOMMENDATIONS}

This study was a cross sectional survey, which does not examine the effect the online brand community on individual consumers before and after the engagement with a online virtual brand community. Therefore a longitudinal survey of individual virtual brand engagement is recommended with qualitative explanations of the various constructs like trust and loyalty are developed over time withing the community. This can unravel or decompose the composition of online trust and online loyalty. Further studies could introduce customer-other customer relationships. A comparative study could also be done between product related virtual brand communities and service related virtual brand communities. This can throw more light on which sector (product or service) performs better with the use of virtual community. 


\section{REFERENCES}

Aaker, D. A., 1991. Managing Brand Equity: Capitalizing on the Value of a Brand Name, NY: The Free Press.

Alharthey, B., 2020. The Role of Online Trust in Forming Online Shopping Intentions. International Journal of Online Marketing (IJOM), 10(1), 32-57.

Angel, R., and Sexsmith, J., 2009. Social networking: the view from the C-suite. Ivey Business Journal, 73(4), 5.

Baldinger, A. L., and Rubinson, J., 1996. Brand loyalty: the link between attitude and behavior. Journal of Advertising Research, 36(6), 22-35.

Batra, R. et al, 2012. Brand love. Journal of Marketing, 76(2), 1-16.

Barnet, K., and Ferris, S. P., 2016. Brand Loyalty and Online Brand Communities: Is Brand Loyalty Being Strengthened Through Social Media? International Journal of Online Marketing (IJOM), 6(3), 50-61.Bayraktar, P. \& Yildirim, S., 2019. Identification of the factors affecting customer engagements in online brand communities: A pilot study. IADIS Internatalional Journal on WWW/Internet Vol. 17, No. 1, pp. 14-29 ISSN: 1645-7641

Bennett, R., \& Rundle-Thiele, S., 2002. A comparison of attitudinal loyalty measurement approaches. Journal of brand management, 9(3), 193-209.

Bowen, G., and Bowen, R., 2020. Differences and Similarities: Brand Trust Offline and Online. In Global Branding: Breakthroughs in Research and Practice (pp. 466-498). IGI Global.

Campbell, C., Pitt, L. F., Parent, M., and Berthon, P. R., 2011. Understanding consumer conversations around ads in a Web 2.0 world. Journal of Advertising, 40(1), 87-102.

Casaló, L. V., Flavián, C., and Miguel, G., 2008. Promoting Consumer's Participation in Virtual Brand Communities: A New Paradigm in Branding Strategy. Journal of Marketing Communications, 14, 19-36.

Casalo, L. V., Flavian, C. and Guinaliu, M., 2010. Some antecedents and effects of participation in Spanish virtual brand communities. International Journal of Web Based Communities, 6(1), 25.

Cha, J., 2009. Shopping on Social Networking Websites: Attitudes towards real versus virtual items. Journal of Interactive Advertising, 10, 77-93.

Chaudhuri, A., and Holbrook, M. B., 2001. The chain of effects from brand trust and brand affect to brand performance: The role of brand loyalty. Journal of Marketing, 65, 81-93.

Chi, H. H., 2011. Interactive digital advertising vs. virtual brand community: Exploratory study of user motivation and social media marketing responses in Taiwan. Journal of Interactive Advertising, 12(1), 44-61.

Chin, W. W., 1998. The partial least squares approach to structural equation modeling. Modern Methods for Business Research, 295(2), 295-336.

Fournier, S., and Avery, J., 2011. The uninvited brand. Business Horizons, 54(3), 193-207.

Georgi, D., \& Mink, M., 2013. eCCIq: The quality of electronic customer-to-customer interaction. Journal of Retailing and Consumer Services, 20(1), 11-19.

Habibi, M. R., Laroche, M., and Richard, M. O., 2014. The roles of brand community and community engagement in building brand trust on social media. Computers in Human Behavior, 37, 152-161.

Howe, J. (2006). The rise of crowdsourcing. Wired Magazine, 14(6), 1-4.

Iglesias, O., Singh, J. J., and Batista-Foguet, J. M., 2011. The role of brand experience and affective commitment in determining brand loyalty. Journal of Brand Management, 18(8), 570-582.Jacoby, J. and Chestnut, R.W., 1978. .Brand Loyalty: Measurement and Management. New York: Wiley.

Kapferer, J.-N., 2008. The New Strategic Brand Management: Creating and Sustaining Brand Equity Long Term. London: Kogan Page Ltd.Kapferer, J. N., 1997. Managing luxury brands. Journal of brand management, 4(4), 251-259. 
IADIS International Journal on WWW/Internet

Kaplan, A. M., and Haenlein, M., 2010. Users of the world, unite! The challenges and opportunities of Social Media. Business Horizons, 53(1), 59-68.

Keller, K. L., 1998. Strategic Brand Management, Prentice Hall, Upper Saddle River, New Jersey.

Lau, G. T., and Lee, S. H., 1999. Consumers' Trust in Brand and their link to Brand Loyalty. Journal of Market Focused Management, 4, 341370.

Liu, L., Lee, M. K., Liu, R., and Chen, J., 2018. Trust transfer in social media brand communities: The role of consumer engagement. International Journal of Information Management, 41, 1-13.Mangold, W. G., \& Faulds, D. J. 2009. Social media: The new hybrid element of the promotion mix. Business horizons, 52(4), 357-365.

Ming, T.T., Ismail, H.B., and Rasiah, D., 2011. Hierarchical Chain of Consumer-Based Brand Equity: Review From The Fast Food Industry. International Business \& Economics Research Journal, 10(9), 67-80.Morgan, R. M., \& Hunt, S. D., 1994. The commitment-trust theory of relationship marketing. Journal of marketing, 58(3), 20-38.

Muñiz, Jr, A. M., and Schau, H. J., 2007. Vigilante marketing and consumer-created communications. Journal of Advertising, 36(3), 35-50.

Nielsen.com, 2012. State of The Media - The Social Media Report 2012. Retrieved December 2019, from http://www.nielsen.com/us/en/insights/reports/2012/state-of-the-media-the-social-media-report2012.html

Oliver, R. L.,1997. Satisfaction: A behavioral perspective on the consumer. New York: McGraw-Hill.Reyneke, M., Pitt, L. and Berthon, P.R., 2011. Luxury wine brand visibility in social media: an exploratory study. International Journal of Wine Business Research, Vol. 23 No. 1, pp. 21-35. https://doi.org/10.1108/17511061111121380

Ringle, C. M., Wende, S., and Becker, J. M. (2015). SmartPLS 3. SmartPLS GmbH, Boenningstedt. Journal of Service, Science and Managment, 10(3).

Saunders, M., Lewis, P., \& Thornhill, A., 2012. Research methods for business students, 696. Essex: Pearson Education Limited.

Sohail, M. S., Hasan, M. and Sohail, A. F., 2020. The Impact of Social Media Marketing on Brand Trust and Brand Loyalty: An Arab Perspective. International Journal of Online Marketing (IJOM), 10(1), 15-31.

Stokburger-Sauer, N., 2010. Brand community: Drivers and outcomes. Psychology \& Marketing, 27(4), 347-368.

Zeng, F., Huang, L., and Dou, W., 2009. Social factors in user perceptions and responses to advertising in online social networking communities. Journal of Interactive Advertising, 10(1), 1-13. 